\title{
Konstruksi Instrumen Tes Keterampilan Berpikir Kritis Terkait Materi Suhu dan Kalor
}

\author{
Desti Ritdamaya ${ }^{a}$, Andi Suhandi \\ Pasca Sarjana Jurusan Pendidikan Fisika UPI, Jalan Dr. Setiabudhi, Bandung, 40154 \\ a)Email: ummunafisah1910@yahoo.com
}

\begin{abstract}
This study was aimed to construct a test instrument for assess critical thinking skills of high school students on the concept heat and temperature. The research using a mixed method with sequential exploratory design, consisting of: 1) the preliminary study phase; 2) the design and review phase; 3) testing phase involving 187 high school students. Test instruments in the form of essays, consisting of 22 questions contain 5 indicator and 8 sub indicators of critical thinking skills expressed by Ennis, with the questions that are qualitative and contextual. The quality test instruments is valid and high reliability. Based on the results of hypothesis testing two different average values, the result is test instrument can distinguish between the critical thinking skills of students who had learning process which to exercise critical thinking skills with students who had the learning process which not to exercise critical thinking skills.
\end{abstract}

Keywords: critical thinking skills test instruments, heat and temperature

\begin{abstract}
Abstrak
Penelitian ini bertujuan untuk mengonstruksi instrumen tes yang mengases keterampilan berpikir kritis siswa Sekolah Menengah Atas pada materi suhu dan kalor. Metode penelitian menggunakan mixed method dengan desain sequential exploratory yang terdiri atas: 1) tahap studi pendahuluan; 2) tahap perancangan dan penelaahan instrumen tes; 3) tahap pengujian instrumen tes yang melibatkan 187 siswa Sekolah Menengah Atas. Instrumen tes yang dikonstruksi dalam bentuk essai, terdiri atas 22 soal memuat 5 indikator dan 8 sub indikator keterampilan berpikir kritis yang dikemukakan oleh Ennis, dengan soal-soal yang bersifat kualitatif dan kontekstual. Kualitas instrumen tes yang dikonstruksi valid dan memiliki reliabilitas dengan kriteria tinggi. Berdasarkan hasil uji hipotesis beda 2 nilai rata-rata, diperoleh hasil yaitu instrumen tes yang dikonstruksi dapat membedakan keterampilan berpikir kritis antara siswa yang mendapatkan proses pembelajaran yang melatihkan keterampilan berpikir kritis dengan siswa yang mendapatkan proses pembelajaran yang tidak melatihkan keterampilan berpikir kritis.
\end{abstract}

Kata-kata kunci: instrumen tes keterampilan berpikir kritis, suhu dan kalor

\section{PENDAHULUAN}

Pembelajaran Fisika menekankan penggunaan pendekatan saintifik untuk membangun pengetahuan dan pemahaman siswa terhadap produk keilmuannya melalui langkah-langkah kegiatan saintis. Melalui pendekatan ini diharapkan dapat mencapai standar kompetensi pembelajaran fisika 
yang telah ditetapkan dalam kurikulum. Salah satu kompetensi pembelajaran fisika yang tertuang dalam Permendikbud nomor 64 tahun 2013 yaitu mengembangkan keterampilan berpikir kritis melalui pembelajaran fisika. Ini menunjukkan bahwa proses maupun asesmen pembelajaran fisika harus berorientasi untuk mengembangkan keterampilan berpikir kritis siswa.

Berpikir kritis adalah penalaran dan berpikir reflektif yang difokuskan untuk memutuskan apa yang diyakini dan dilakukan (Ennis 1993). Keterampilan berpikir kritis bagi individu berperan penting dalam menganalisis pemikiran, argumen, masalah dengan teliti berdasarkan kredibilitas sumber data dan informasi; berusaha memberikan penilaian terhadap pemikiran, argumen, masalah dengan benar; mampu memecahkan permasalahan dengan logis dalam berbagai situasi dan membuat keputusan berdasarkan pertimbangan bukti dan fakta yang relevan.

Keterampilan berpikir kritis bukanlah keterampilan bawaan sejak lahir sehingga keterampilan ini dapat diterapkan, dilatih dan dikembangkan melalui proses dan asesmen pembelajaran. Dalam proses pembelajaran guru sebagai mediator dan fasilitator mendesain dan menerapkan metode, model atau strategi yang dapat melatihkan dan mengembangkan keterampilan berpikir kritis siswa.

Permendikbud nomor 104 tahun 2014 menyatakan "penilaian hasil belajar oleh pendidik dilakukan terhadap penguasaan tingkat kompetensi sebagai capaian pembelajaran dan penilaian hasil belajar oleh pendidik dilaksanakan dengan menggunakan instrumen penilaian." Pernyataan ini menunjukkan bahwa kompetensi keterampilan berpikir kritis sebagai salah satu sasaran capaian dalam pembelajaran fisika harus dilakukan penilaian selama dan setelah proses pembelajaran berlangsung, maka dibutuhkan adanya suatu instrumen yang akan digunakan untuk menilai dan memperoleh kualitas data/informasi yang tepat dan benar tentang gambaran perkembangan kualitas dan ketercapaian keterampilan berpikir kritis siswa.

Penggunaan instrumen asesmen/penilaian keterampilan berpikir kritis yang tepat disertai dengan latihan secara kontinu dan berkesinambungan, juga dapat melatih dan mengembangkan keterampilan berpikir kritis siswa. Hal ini karena asesmen berperan sebagai feedback bagi guru agar dapat memperbaiki dan meningkatkan kualitas pembelajarannya dari waktu ke waktu yang mengarah pada ketercapaian keterampilan berpikir kritis siswa. Feedback bagi siswa tentang kualitas keterampilan berpikir kritisnya, sehingga siswa akan mencoba untuk meningkatkannya dengan belajar lebih baik dari materi-materi yang menstimulus berpikir kritis.

Tetapi fakta di lapangan berdasarkan hasil studi pendahuluan yang dilakukan penulis pada beberapa sekolah di kota Bandung dengan melakukan wawancara terhadap guru mata pelajaran fisika, penilaian/asesmen terhadap keterampilan berpikir kritis siswa dalam pembelajaran fisika belum pernah dilakukan. Alasannya belum memiliki instrumen untuk mengases keterampilan berpikir kritis siswa. Pihak guru sendiri pun belum bisa mengembangkan sendiri instrumen keterampilan berpikir kritis tersebut. Kebanyakan sistem asesmen/penilaian yang dilakukan oleh guru mengunakan tes tertulis yang disesuaikan dengan standar nasional dan merujuk pada tes dalam Ujian Nasional yang berbasis penguasaan konsep. Nuryani juga menyatakan hal yang sama bahwa titik berat hasil belajar masih terfokus pada penguasaan konsepnya, maka selama ini instrumen yang dikembangkan pun senantiasa terkait dengan pengukuran pencapaian konsep (Rustaman 2008).

Berdasarkan hasil kajian literatur, instrumen yang mengases keterampilan berpikir kritis siswa memang minim ketersediaannya. Cornell Critical Thinking Test Level X And $Z$ dibuat oleh Ennis \& Millmandan The Ennis-Weir Critical Thinking Essay Test dibuat oleh Ennis dan Weir merupakan tes keterampilan berpikir kritis dengan materi yang diujikan bersifat umum (Ennis 1993). Terdapat beberapa tes keterampilan berpikir kritis yang bermuatan konten pelajaran, seperti konten kimia dibuat oleh Kartimi dkk (2013) dan Citrawati (2012); konten matematika dibuat oleh Ismaimuza dkk (2013); dan konten biologi dibuat oleh Amalia, S.N (2012). Penulis belum menemukan instrumen keterampilan berpikir kritis bermuatan konten fisika yang valid dan reliabel.

Berdasarkan pemaparan di atas, ketersediaan instrumen tes yang mengases keterampilan berpikir kritis siswa yang bermuatan konten fisika mutlak dibutuhkan. Maka penulis melakukan penelitian yang mengkonstruksi instrumen asesmen keterampilan berpikir kritis bermuatan konten fisika berupa tes. Tes yang dikonstruksi diharapkan dapat mengases dengan baik keterampilan berpikir kritis siswa dalam konten fisika. Rumusan masalah dalam makalah ini yaitu:

- Bagaimana karakteristik instrumen tes keterampilan berpikir kritis terkait materi suhu dan kalor yang dikonstruksi? 
- Bagaimana kualitas instrumen tes keterampilan berpikir kritis terkait materi suhu dan kalor yang dikonstruksi ditinjau dari aspek validitas dan reliabilitasnya ?

- Apakah instrumen tes yang dikonstruksi dapat membedakan keterampilan berpikir kritis antara siswa yang mendapatkan proses pembelajaran yang melatihkan keterampilan berpikir kritis dengan siswa yang mendapatkan proses pembelajaran yang tidak melatihkan keterampilan berpikir kritis ?

Ennis mengemukakan ada lima indikator keterampilan berpikir kritis. Setiap indikator terdiri atas sub indikator yang memiliki keterkaitan makna satu sama lainnya (1985). Penjabaran indikator dan sub indikator keterampilan berpikir kritisnya sebagai berikut:

- Klarifikasi dasar (elementary clarification), meliputi: memfokuskan pertanyaan; menganalisis argumen; mengajukan pertanyaan dan menjawab pertanyaan klarifikasi atau tantangan

- Dasar dalam mengambil keputusan atau dukungan (the basis for the decision/ basic support), meliputi: mempertimbangkan kredibilitas sumber; melakukan observasi dan menilai laporan observasi

- Inferensi (inference), meliputi : deduksi dan menilai deduksi; induksi dan menilai induksi; membuat dan menilai pernyataan nilai

- Klarifikasi lanjut (advanced clarification), meliputi: mendefinisikan istilah dan menilai definisi; mengidentifikasi asumsi

- Strategi dan taktik (strategies and tactics), meliputi: menentukan tindakan; berinteraksi dengan orang lain.

Untuk memahami makna setiap indikator dan sub indikator berpikir kritis, Ennis memberikan sketsa hubungan antara makna masing-masing indikator dalam keterampilan berpikir kritis yang ditunjukkan oleh GAMBAR 1 (Ennis 1991).

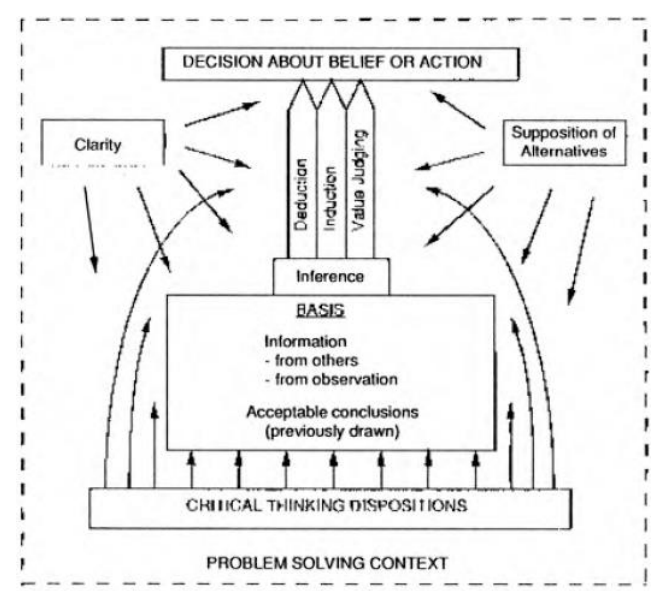

GAMBAR 1. Sketsa Konsepsi Berpikir Kritis (Ennis 1991)

Membuat keputusan tentang apa yang diyakini dan dilakukan umumnya terjadi dalam konteks pemecahan masalah. Pemecahan masalah ini memerlukan penekanan pada penjelasan dan dukungan dari berbagai alternatif. Untuk memutuskan apa yang diyakini dan dilakukan harus mempunyai atau mencari dasar. Dasar ini terdiri dari informasi (yang diperoleh dari sumber lain atau hasil observasi) dan proposisi dari proses berpikir sebelumnya. Mengacu pada dasar ini maka dapat dilakukan inferensi. Inferensi dapat dilakukan melalui tiga proses yaitu induksi, deduksi dan membuat pernyataan nilai. Dari inferensi inilah dapat menuju pada kesimpulan berupa keputusan tentang apa yang diyakini dan dilakukan. Proses untuk membuat keputusan ini akan lebih komprehensif apabila menggabungkan antara disposisi berpikir kritis dan keterampilan berpikir kritis. Mempertahankan keputusan yang telah dibuat akan selalu ada dan sering dipresentasikan ketika berinteraksi dengan orang lain baik secara lisan maupun tulisan.

Berdasarkan kajian literatur terhadap hasil penelitian, beberapa metode/ model/ strategi pembelajaran yang dapat melatihkan dan mengembangkan keterampilan berpikir kritis siswa antara lain: 
- Pembelajaran berbasis inkuiri (Azismalayeri 2012, Greenwald \& Quitadamo 2014).

- Pembelajaran berbasis masalah (Masek \& Yamin 2012, Susilo 2012).

- Pembelajaran kooperatif (Soirwan 2013, Nezami 2013).

- Pembelajaran menggunakan multimedia interaktif/ berbantuan simulasi virtual (Wiyono 2012, Simon 2014).

- Model pembelajaran kontekstual (Sugiarti \& Bija 2012).

- Model siklus belajar-learning cycle (Udayani 2014, Usmiatiningsih 2015).

- Model pembelajaran konflik kognitif (Sutisna 2013).

- Model pembelajaran berbasis proyek (Sastrika 2013).

- Model pembelajaran discovery (Pratiwi 2014).

\section{METODE}

Metode penelitian menggunakan mixed method dengan desain sequential exploratory. Desain ini dapat digunakan seorang peneliti melatihkan, membangun, mengkonstruksi atau menguji instrumen baru (Creswell 2003). Desain penelitian ini disajikan pada GAMBAR 2.

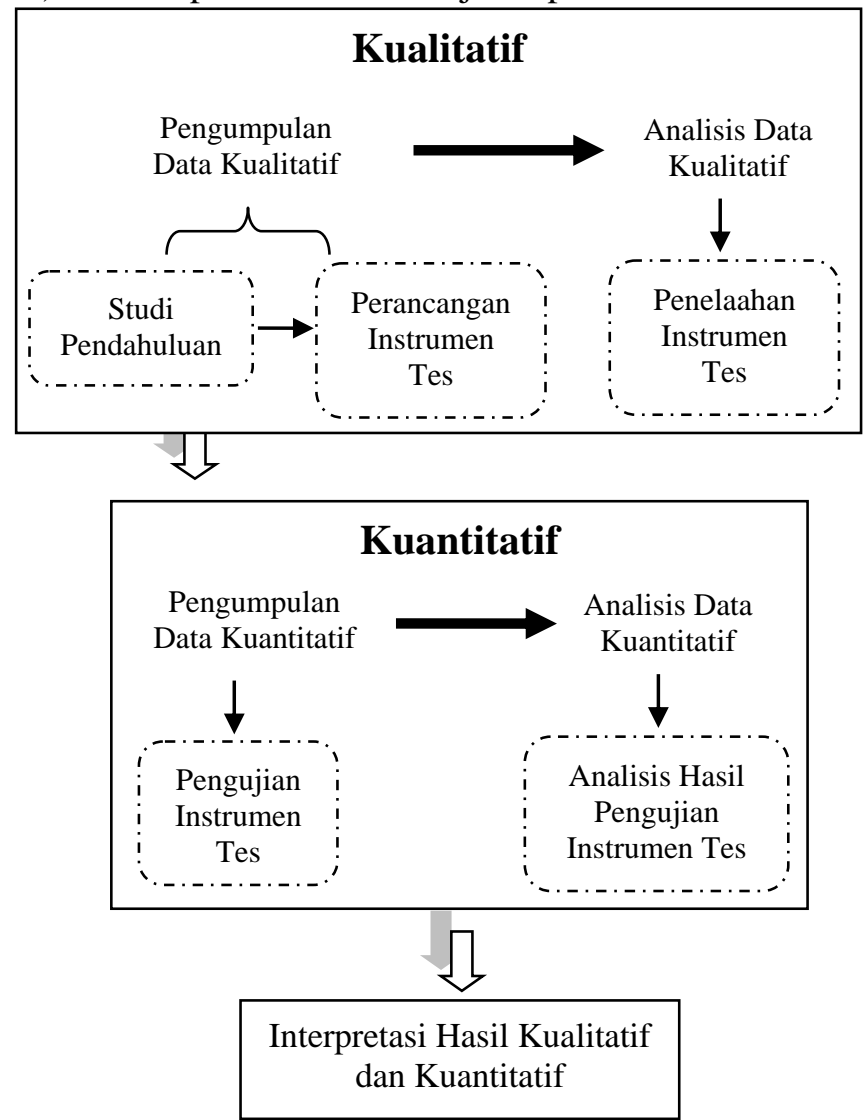

GAMBAR 2. Desain Konstruksi Instrumen Tes

Berdasarkan desain pada GAMBAR 2, maka tahapan konstruksi instrumen tes dalam penelitian ini sebagai berikut:

- Tahap studi pendahuluan, meliputi : studi kebijakan, survey lapangan, dan studi literatur.

- Tahap perancangan dan penelaahaan instrumen tes. Tahap perancangan meliputi: analisis kedalaman materi ajar, pemilihan indikator dan sub indikator keterampilan berpikir kritis, analisis indikator dan sub indikator keterampilan berpikir kritis, pengoperasionalan indikator dan sub indikator keterampilan berpikir kritis, pembuatan deskripsi soal instrumen tes, penulisan soal instrumen tes. Tahap penelaahan meliputi: uji validitas dan reliabilitas. 
- Tahap pengujian instrumen tes, yaitu uji implementasi menggunakan metode quasi experiment dengan desain non equivalent posttest-only control group design. Dalam desain ini, sampel penelitian terbagi atas kelompok eksperimen dan kelompok kontrol yang tidak dipilih secara acak, setelah diberikan perlakuan kedua kelompok memperoleh post test (Sugiyono 2014). Dalam penelitian ini kelompok eksperimen adalah siswa yang mendapatkan proses pembelajaran yang melatihkan keterampilan berpikir kritis, sedangkan kelompok kontrol adalah siswa yang mendapatkan proses pembelajaran yang tidak melatihkan keterampilan berpikir kritis.

Sampel penelitian adalah siswa kelas XI Sekolah Menengah Atas yang telah mendapatkan materi suhu dan kalor. Penentuan sampel menggunakan teknik sampling purposive. Teknik ini digunakan dengan pertimbangan tertentu sesuai dengan tujuan penelitian (Sugiyono 2014). Pertimbangan penulis yaitu ingin memperoleh SMA yang menerapkan proses pembelajaran yang melatihkan keterampilan berpikir kritis dan proses pembelajaran yang tidak melatihkan keterampilan berpikir kritis dalam materi suhu dan kalor. Dalam penelitian ini proses pembelajaran yang melatihkan keterampilan berpikir kritis menggunakan model kooperatif STAD (Student Teams Achievement Division), problem based instruction, learning cycle $5 E$ berbantuan simulasi virtual, sedangkan proses pembelajaran yang tidak melatihkan keterampilan berpikir kritis menggunakan direct instruction dengan metode ceramah. Jumlah sampel dalam penelitian ini terdiri atas: 87 siswa yang mendapatkan proses pembelajaran yang melatihkan keterampilan berpikir kritis dan 100 siswa yang mendapatkan proses pembelajaran yang tidak melatihkan keterampilan berpikir kritis.

Teknik analisis data untuk validitas instrumen dilakukan secara deskriptif terhadap hasil validasi pakar yang berkompeten dalam konten fisika dan pendidikan fisika.

Reliabilitas instrumen tes menggunakan test-retest method. Hasil reliabilitas tes dalam uji coba pertama dan kedua dihitung korelasinya, kemudian nilai koefisien korelasinya dianggap sebagai nilai koefisien reliabilitasnya. Untuk menghitung korelasi, menggunakan persamaan Pearson productmoment correlation coefficient sebagai berikut:

$$
r_{x y}=\frac{n \sum x_{i} \mathbb{Y}_{i}-\left(\sum x_{i}\right)\left(\sum Y_{i}\right]}{\sqrt{\left[n \sum x_{i}^{2}-\left(\sum x_{i}\right)^{2}\right]\left[n \sum Y_{i}^{2}-\left(\sum Y_{i}\right)^{2}\right]}}
$$

dengan $r_{x y}$ adalah koefisien korelasi variabel $\mathrm{x}$ dan y (Arikunto 2013).

Analisis untuk mendapatkan gambaran kemampuan instrumen tes dalam membedakan keterampilan berpikir kritis antara siswa yang mendapatkan proses pembelajaran yang melatihkan keterampilan berpikir krits dan siswa yang mendapatkan proses pembelajaran yang tidak melatihkan keterampilan berpikir kritis menggunakan uji hipotesis beda 2 nilai rata-rata. Hipotesisnya sebagai berikut:

"Terdapat perbedaan signifikan keterampilan berpikir kritis antara siswa yang mendapatkan proses pembelajaran yang melatihkan keterampilan berpikir kritis dengan siswa yang mendapatkan proses pembelajaran yang tidak melatihkan keterampilan berpikir kritis."

Apabila data hasil pengujian keterampilan berpikir kritis siswa memenuhi persyaratan uji statistik parametik yaitu data berdistribusi normal dan memiliki varians data yang homogen, maka uji hipotesis beda 2 nilai rata-rata post test menggunakan persamaan sebagai berikut:

$$
\mathrm{z}=\frac{\overline{x_{1}}-\overline{x_{2}}}{\sqrt{\left(\frac{\sigma_{1}^{2}}{n_{1}}\right)+\left(\frac{\sigma_{2}^{2}}{n_{2}}\right)}}
$$

dengan $\overline{X_{1}}$ adalah nilai rata-rata kelompok eksperimen, $\overline{X_{2}}$ adalah nilai rata-rata kelompok kontrol, $\sigma_{1}$ adalah simpangan baku kelompok eksperimen, $\sigma_{2}$ adalah simpangan baku kelompok kontrol, $\mathrm{n}_{1}$ adalah jumlah sampel kelompok eksperimen dan $\mathrm{n}_{2}$ adalah jumlah sampel kelompok kontrol (Sudjana 2013). Hasil uji z akan ditelaah dengan membandingkan nilai yang sudah diperoleh dengan nilai pada tabel distribusi $\mathrm{z}$ pada taraf signifikansi $(\alpha=0,05)$. Jika nilai $\mathrm{Z}_{\text {hitung }}>\mathrm{Z}_{\mathrm{tabel}}$, maka hipotesis penelitian diterima.

Apabila data hasil pengujian keterampilan berpikir kritis siswa tidak memenuhi persyaratan uji statistik parametik maka uji hipotesis beda 2 nilai rata-rata, menggunakan uji statistik non parametrik yaitu uji Mann-Whitney Test. 


\section{HASIL DAN PEMBAHASAN}

\section{Karakteristik Instrumen Tes Keterampilan Berpikir kritis}

Penulis merancang tes keterampilan berpikir kritis terkait materi suhu dan kalor terdiri atas 26 soal yang mengacu pada indikator keterampilan berpikir krtitis yang dikemukakan oleh Ennis meliputi 5 indikator dan 8 sub indikator. Penulis memilih indikator keterampilan berpikir kritis menurut Ennis karena tiap indikator yang dikemukakan terdiri atas sub indikator yang lebih lengkap. Setiap sub indikator terdiri atas sub-sub indikator yang menjelaskan lebih detail dan rinci makna dari sub indikator tersebut.

Instrumen tes yang dikonstruksi oleh penulis dalam bentuk open ended yaitu essai. Ennis menjelaskan bentuk asesmen berpikir kritis yang komprehensif adalah dalam bentuk open ended, sedangkan dalam bentuk tes pilihan ganda kurang komprehensif karena akan kehilangan banyak indikator berpikir kritis yang diujikan (Ennis 1993). Hal ini bersesuaian dengan pendapat Ku yang menyatakan bahwa tes open ended lebih dapat menangkap konstruksi indikator berpikir kritis dibandingkan tes pilhan ganda karena lebih memiliki sensitifitas (Ku 2009).

Setiap item soal yang dikonstruksi oleh penulis, terdiri atas informasi awal dan pertanyaan. Informasi awal diberikan sebagai stimulus berpikir kritis siswa, sehingga siswa dapat memproses informasi tersebut dan mengkaitkannya dengan pertanyaan soal. Informasi awal ini berupa teks bacaan, kasus/ masalah, gambar, tabel dan grafik yang berbasis pada konten materi suhu dan kalor. Jadi siswa dalam menjawab pertanyaan soal berdasarkan keterampilan berpikirnya dalam memproses informasi awal bukan berdasarkan pada aspek hafalannya terhadap konsep-konsep materi suhu dan kalor. Karakteristik soal tes keterampilan berpikir tingkat tinggi salah satunya keterampilan berpikir kritis, memang menuntut siswa mengeksplorasi proses berpikirnya dengan mengkaitkan dan mengkonstruksi informasi yang ada dalam tes untuk mengambil suatu keputusan atau pemecahan masalah pada pertanyaan soal.

Soal-soal dalam instrumen tes yang dikonstruksi bersifat kualitatif dan kontekstual. Soal yang bersifat kualitatif maksudnya soal yang berbasis pada makna fisis dari konsep-konsep materi (Wherdiana 2008). Soal-soal yang bersifat kualitatif lebih dapat mengidentifikasi pemahaman siswa terhadap makna khusus yang terkandung dalam konsep-konsep fisika ketimbang soal-soal yang bersifat kuantitatif (hitungan). Mundilarto menjelaskan bahwa soal fisika yang menuntut pemecahan masalah secara formalisme matematis saja tidak akan efektif apabila digunakan sebagai alat evaluasi tingkat pemahaman konseptual serta kemampuan berpikir siswa (Mundilarto 2001).

Soal bersifat kontekstual maksudnya fenomena atau masalah yang disajikan dalam soal terkait dengan konteks kehidupan sehari-hari. Soal-soal yang bersifat kontekstual penting untuk disajikan agar siswa menyadari bahwa fenomena fisis dalam konsep-konsep fisika dekat dengan kehidupan sehari-hari dan dapat diaplikasikan dalam teknologi yang akhirnya dapat dimanfaatkan untuk kemudahan hidup manusia.

\section{Validitas dan Reliabilitas Instrumen Tes}

Instrumen tes yang dirancang oleh penulis dilakukan uji validitas dengan cara meminta pertimbangan kepada lima pakar yang terdiri atas dua pakar pendidikan fisika dan tiga pakar konten fisika.

Hasil validasi dari para pakar yaitu: terdapat 22 soal yang persentasenya $100 \%$ diberikan penilaian sesuai dengan indikator/sub indikator keterampilan berpikir kritis, sedangkan 4 soal yang persentasenya $80 \%$ diberikan penilaian sesuai dengan indikator/sub indikator keterampilan berpikir kritis. Ini artinya soal-soal yang dirancang oleh penulis telah sesuai dengan indikator/ subindikator keterampilan berpikir kritis.

Semua validator memberikan penilaian bahwa tidak ada soal yang tidak bisa digunakan. Terdapat 3 soal yang persentasenya $80 \%$ diberikan penilaian revisi, 2 soal yang persentasenya $60 \%$ diberikan penilaian revisi. Terdapat 3 soal yang persentasenya $100 \%$ diberikan penilaian bisa digunakan tanpa ada revisi. Terdapat 11 soal yang persentasenya $80 \%$ diberikan penilaian bisa digunakan tanpa ada revisi. Terdapat 7 soal yang persentasenya $60 \%$ diberikan penilaian bisa digunakan tanpa ada revisi. 
Jadi kesimpulannya terdapat 5 soal yang diberikan penilaian revisi dengan persentase $>50 \%$ dan terdapat 21 soal yang diberikan penilaian bisa digunakan tanpa ada revisi dengan persentase $>50 \%$.

Saran dari pakar digunakan untuk memperbaiki instrumen tes yang sudah dirancang, sehingga instrumen tes benar-benar layak digunakan dalam uji coba dan implementasi instrumen tes Setelah dilakukan revisi terhadap item soal, maka jumlah item soal yang digunakan oleh penulis dalam uji coba dan implementasi instrumen tes yaitu 22 soal.

Instrumen tes hasil revisi setelah proses validasi, dilakukan uji coba untuk memperoleh nilai reliabilitasnya. Uji coba ini dilakukan pada salah satu Sekolah Menengah Atas Negeri di Kabupaten Banjar Provinsi Jawa Barat, dengan melibatkan satu kelas yang menerapkan proses pembelajaran yang menggunakan model pembelajaran inkuiri terbimbing dengan strategi peer instruction. Berdasarkan hasil penelitian proses pembelajaran berbasis inkuiri dapat melatihkan keterampilan berpikir kritis siswa, sehingga SMA yang terpilih ini memang layak menjadi sampel uji coba (Azismalayeri 2012, Greenwald 2014).

Reliabilitas instrumen tes keterampilan berpikir kritis menggunakan metode ulang (test-retest method). Dari hasil uji coba diperoleh nilai reliabilitas instrumen tes yaitu 0,71, artinya instrumen tes yang dikonstruksi oleh penulis memiliki reliabilitas dengan kriteria tinggi.

\section{Kemampuan Instrumen Tes}

Sebelum dilakukan uji hipotesis beda 2 nilai rata-rata, dilakukan terlebih dahulu uji normalitas dan homogenitas. Uji normalitas yang digunakan yaitu uji Kolmogorov-Smirnov melalui bantuan piranti lunak pengolah data SPSS Statistics.16.0 dengan kriteria pengujian pada signifikansi $>0.05$ maka data berdistribusi nor mal. Sedangkan uji homogenitas menggunakan Test of Homogeneity of Variances dengan bantuan piranti lunak pengolah data SPSS Statistics.16.0 dengan kriteria pengujian pada signifikansi > 0.05 maka data mempunyai varians data yang sama (homogen). Analisis uji normalitas dan homogenitas data pengujian keterampilan berpikir kritis siswa mendapatkan hasil yang disajikan pada TABEL 1.

TABEL 1. Hasil Uji Normalitas dan Homogenitas

\begin{tabular}{|c|c|c|c|c|c|}
\hline No & $\mathbf{U j i}$ & Kelompok & $\mathbf{N}$ (siswa) & Sig. & Interpretasi \\
\hline 1 & Normalitas & $\begin{array}{c}\text { Eksperimen } \\
\text { Kontrol }\end{array}$ & $\begin{array}{c}87 \\
100\end{array}$ & $\begin{array}{l}0.41 \\
0.24\end{array}$ & Data berdistribusi normal \\
\hline 2 & Homogeni tas & $\begin{array}{c}\text { Eksperi men } \\
\text { Kontrol } \\
\end{array}$ & $\begin{array}{c}87 \\
100 \\
\end{array}$ & 0.47 & Varians data homogen \\
\hline
\end{tabular}

Tahapan selanjutnya yaitu ingin mendapatkan gambaran kemampuan instrumen tes yang dikonstruksi dalam membedakan keterampilan berpikir kritis antara siswa yang mendapatkan proses pembelajaran yang melatihkan keterampilan berpikir kritis dengan siswa yang mendapatkan proses pembelajaran yang tidak melatihkan keterampilan berpikir kritis, dengan cara melakukan uji hipotesis beda 2 nilai rata-rata post test antara kelompok eksperimen dan kelompok kontrol. Data pengujian keterampilan berpikir kritis siswa berdistribusi normal dan homogen, maka uji hipotesis beda 2 rata-rata post test menggunakan persamaan 2 . Analisis statistik untuk uji hipotesis beda 2 nilai rata-rata post test mendapatkan hasil yang disajikan pada TABEL 2.

TABEL 2. Hasil Uji Hipotesis Beda 2 Nilai Rata-Rata Post Test

\begin{tabular}{cccccc}
\hline Kelompok & Rata-rata & Standar deviasi & $\mathbf{Z}_{\text {hi tung }}$ & $\mathbf{Z}_{\mathbf{0 . 0 5}}$ & Interpretasi \\
\hline Eksperimen & 38.7 & 5.31 & \multirow{2}{*}{9.06} & \multirow{2}{*}{1.96} & Hipotesis diterima \\
Kontrol & 29.6 & 8.29 & & & \\
\hline
\end{tabular}

Berdasarkan data dalam TABEL 2, teridentifikasi bahwa hipotesis penelitian diterima. Artinya terdapat perbedaan antara nilai rata-rata post test kelompok eksperimen dengan nilai rata-rata kelompok kontrol, sehingga instrumen tes yang dikonstruksi dapat membedakan keterampilan berpikir kritis antara siswa yang mendapatkan proses pembelajaran yang melatihkan keterampilan berpikir kritis dengan siswa yang mendapatkan proses pembelajaran yang tidak melatihkan keterampilan berpikir kritis. 
Berdasarkan banyak hasil penelitian, siswa yang mendapatkan proses pembelajaran yang melatihkan keterampilan berpikir kritis memang akan memberikan dampak pada peningkatan keterampilan berpikir kritis dibandingkan siswa yang mendapatkan proses pembelajaran yang tidak melatihkan keterampilan berpikir kritis. Terdapat perbedaan peningkatan nilai dalam pengujian keterampilan berpikir kritisnya, siswa yang diterapkan proses pembelajaran yang melatihkan keterampilan berpikir kritis terjadi peningkatan nilai keterampian berpikir kritis yang lebih tinggi.

Hal ini terjadi karena proses pembelajaran yang melatihkan keterampilan berpikir kritis bersifat student centered yang memberikan kesempatan kepada siswa untuk membangun dan mengkonstruksi pengetahuan dan pemahamannya sendiri terhadap produk keilmuan fisika. Implikasinya produk keilmuan fisika ini akan dipahami secara lebih mendalam hakikatnya oleh siswa, tidak menjadikannya sebagai kebenaran final tetapi selalu berusaha untuk membuktikan kevalidannya dengan bukti yang logis dan kuat. Sedangkan dalam proses pembelajaran yang tidak melatihkan keterampilan berpikir kritis bersifat teacher centered. Dalam proses pembelajaran ini lebih didominasi oleh guru dengan menekankan transfer produk keilmuan fisika dari guru ke siswa, dan kurang memberikan kesempatan kepada siswa untuk mengeksplorasi keterampilan berpikirnya.

\section{KESIMPULAN}

Instrumen tes keterampilan berpikir kritis terkait materi suhu dan kalor yang dikonstruksi memiliki karakteristik sebagai berikut:

1. Instrumen tes dalam bentuk essai karena lebih komprehensif dan lebih dapat menangkap konstruksi indikator dan sub indikator keterampilan berpikir kritis.

2. Instrumen tes terdiri atas 22 soal memuat 5 indikator dan 8 sub indikator keterampilan berpikir kritis yang dikemukakan oleh Ennis.

3. Setiap item soal mengandung sejumlah informasi sebagai stimulus berpikir yang dapat digunakan siswa dalam menjawab pertanyaan berupa teks bacaan, kasus/masalah, gambar, tabel dan grafik.

4. Soal-soal dalam instrumen tes bersifat kualitatif dan kontekstual, fenomena atau masalah yang disajikan dalam soal terkait dengan konteks kehidupan sehari-hari.

Kualitas instrumen tes yang dikonstruksi valid dan reliabel untuk mengases keterampilan berpikir kritis. Validator menyatakan bahwa instrumen tes yang dikonstruksi sesuai dengan indikator/sub indikator keterampilan berpikir kritis dan bisa digunakan untuk mengases keterampilan berpikir kritis siswa. Nilai koefisien reliabilitas instrumen tes yaitu 0,71, artinya instrumen tes yang dikonstruksi oleh penulis memiliki reliabilitas dengan kriteria tinggi.

Instrumen tes yang dikonstruksi dapat membedakan keterampilan berpikir kritis antara siswa yang mendapatkan proses pembelajaran yang melatihkan keterampilan berpikir kritis dengan siswa yang mendapatkan proses pembelajaran yang tidak melatihkan keterampilan berpikir kritis.

\section{DAFTAR ACUAN}

Amalia, S.N. (2012). Pengembangan Soal Esai Berpikir Kritis Dan Profil Pencapaiannya Di SMA Negeri Kota Bandung Pada Tema Sistem Organ. Tesis Magister pada SPS UPI: Tidak Diterbitkan.

Arikunto, Suharsimi. (2013). Dasar-Dasar Evaluasi Pendidikan Edisi 2. Jakarta : Bumi Aksara.

Azismalayeri et.al. (2012). The Impact of Guided Inquiry Methods of Teaching on The Critical Thinking of High School Students. Journal of Education And Practice. Vol 3, No 10, 2012

Citrawati, C. (2012). Pengembangan Tes Keterampilan Berpikir Kritis Siswa SMA Pada Materi Pokok Larutan Asam Basa. Tesis Pada SPS UPI : Tidak Diterbitkan

Creswell et.al. (2003). Research Design Qualitative, Quantitative, and Mixed Methods Approaches. International Educational and Proffesional Publisher. Diakses Februari 2015. Tersedia : http://isites.harvard.edu/fs/docs/icb.topic1334586.files/2003 
Ennis, R.H. (1985). Logical Basis for Measuring Critical Thinkin g Skills. Educational Leadership,43(2), 44-48. Diakses Februari 2015. Tersedia : http://www.ascd.org/ASCD/pdf/journals/ed_lead/el_198510_ennis.pdf

Ennis, R.H. (1991). Critical Thinking : A Streamlined Conception. Teaching Philosophy, 14 : 1, March 1991.

Ennis, R.H. (1993). Critical Thinking Asessement. Theory Into Practice. Volume 32, Number 3, Summer 1993.

Greenwald, R \& Ian J. Quitadamo. (2014). A Mind of Their Own: Using Inquiry-based Teaching to Build Critical Thinking Skills and Intellectual Engagement in an Undergraduate Neuroanatomy Course. The Journal of Undergraduate Neuroscience Education (JUNE), Spring 2014, 12(2):A100-A106.

Ismaimuza, D dkk. (2013). Pengembangan Instrumen Kemampuan Berpikir Kritis Matematis Untuk Siswa SMP. Prosiding Seminar Nasional Sains dan Matematika Jurusan Pendidikan MIPA FKIP UNTAD. 2013. ISBN 978-602-8824-49-1

Kartimi. (2013). Pengembangan Alat Ukur Keterampilan Berpikir Kritis Kimia Untuk Siswa SMA. Tesis Magister pada SPS UPI : Tidak Diterbitkan.

Ku, K. Y. (2009). Assessing students' critical thinking performance: Urging for measurements using multi-response format. Thinking Skills and Creativity, 4(2009), 70-76.

Masek \& Yamin. (2012). The Impact of Instructional Methods on Critical Thinking:A Comparison of Problem-Based Learning and Conventional Approach in Engineering Education. International Scholarly Research Network. Volume 2012, Article ID 759241, 6 pages.

Mundilarto. (2001). Pola Pendekatan Siswa Dalam Memecahkan Soal Fisika. Disertasi Doktor pada SPS UPI : Tidak Diterbitkan.

Nezami et.al. (2013). The Effect of Cooperative Learning On the Critical Thinking of High School Students. TJEAS Journal.-2013-3-19/2508-2514.

Pratiwi, F.A. (2014). Pengaruh Penggunaan Model Discovery Learning Dengan Pendekatan Saintifik Terhadap Keterampilan Berpikir Kritis Siswa SMA. Artikel Pendidikan. Diakses maret 2015. Tersedia : http://jurnal.untan.ac.id

Rustaman, Nuryani. (2008). Habits of Mind in Learning Science and Its Assessment. Makalah Pendidikan. Diakses Februari 2015. Tersedia : http://file.upi.edu/Direktori/SPS/PRODI.PENDIDIKAN_IPA/195012311979032.

Sastrika dkk. (2013). Pengaruh Model Pembelajaran Berbasis Proyek Terhadap Pemahaman Konsep Kimia Dan Keterampilan Berpikir Kritis. e-Journal Program Pascasarjana Universitas Pendidikan Ganesha.Volume 3 Tahun 2013.

Simon, N. (2014). Simulated and Virtual Science Laboratory Experiments: Improving Critical Thinking and Higher-Order Learning Skills. Proceedings of Society for Information Technology \& Teacher Education International Conference 2014 (pp. 453-459).

Soirwan, dkk. (2013). Pengaruh Kemampuan Berpikir Kritis Terhadap Penguasaan Konsep Melalui Pembelajaran Kooperatif Tipe STAD. Jurnal Pembelajaran Fisika. Vol 1, No 3.2013. Tersedia : www.unila.ac.id

Sudjana. (2013). Metoda Statistika. Bandung : Tarsito.

Sugiarti \& Bija, S. (2012). Pengaruh Model Pembelajaran Kontekstual Terhadap Kemampuan Berpikir Kritis Siswa Kelas XI IA SMA Negeri 3 Watansoppeng. Jurnal Chemica.Vo/. 13 Nomor 1 Juni 2012, $77-83$

Sugiyono. (2014). Metode Penelitian Pendidikan: Pendekatan Kuantitatif,Kualitatif, dan $R \& D$. Bandung : Alfabeta. 
Susilo dkk. (2012). Model Pembelajaran Ipa Berbasis Masalah Untuk Meningkatkan Motivasi Belajar Dan Berpikir Kritis Siswa SMP. Unnes Science Education Journal, 1 (1) (2012).

Sutisna, A. (2013). Pengembangan Model Pembelajaran Konflik Kognitif Untuk Memfasilitasi Perubahan Konseptual Dan Peningkatan Keterampilan Berpikir Kritis Siswa Pada Materi Termokimia. Tesis Magister Pada Sps Upi : Tidak Diterbitkan.

Udayani, dkk. (2014). Pengaruh Model Siklus Belajar 5E Terhadap Kemampuan Berpikir Kritis IPA Siswa Kelas IV SD Di Desa Kalibukbuk. e-Journal MIMBAR PGSD Universitas Pendidikan Ganesha Jurusan PGSD. Vol. 2 No. 1 Tahun 2014

Usmiatiningsih, E. (2015). Efektivitas Model Pembelajaran 5E Untuk Meningkatkan Keterampilan Berpikir Kritis Pada Siswa Smp Negeri 6 Mataram. Media Bina Ilmiah 1. Volume 9, No. 4, Juni 2015.

Wherdiana, K. (2008). Pengembangan Tes Pemahaman Konsep Fisika Siswa SMA. Disertasi Doktor pada SPS UPI : Tidak Diterbitkan.

Wiyono, K \& Liliasari. (2012). Peningkatan Keterampilan Berpikir Kritis Mahasiswa Calon Guru Dengan Model Mia-Piza. Forum MIPA (Majalah Ilmiah Jurusan PMIPA FKIP Unsri). Volume 14 No.1 Januari 2012. 